\title{
Mathematics 3.0 fraction squares, an educational video game for ludic use in classroom
}

\section{Matemáticas 3.0 fracciones cuadradas, un videojuego educativo para uso lúdico en el aula}

QUIJANO-ABAN, Víctor Manuel†*, CERVERA-EVIA, Gimer Amilcar, MOO-PECH, José Guadalupe and QUIJANO-CRUZ, Bonesí

Universidad Tecnológica Metropolitana

ID $1^{\text {st }}$ Author: Víctor Manuel, Quijnao-Abán / ORC ID: 0000-0002-6192-0797

ID $1^{\text {st }}$ Coauthor: Gimer Amilcar, Cervera-Evia / ORC ID: 0000-0002-5836-6895, CVU CONACYT ID: 259032

ID $2^{\text {nd }}$ Coauthor: José Guadalupe, Moo-Pech / ORC ID: 0000-0003-3566-3106

ID $3^{\text {rd }}$ Coauthor: Bonesí, Quijano-Cruz / ORC ID: 0000-0003-3185-7667, CVU CONACYT ID: 955316

DOI: $10.35429 / J S E M .2020 .20 .7 .26 .32$

Received January 17, 2020; Accepted June 28, 2020

\begin{abstract}
When we talk about video games we associate it with in entertainment, but its use also has extensive benefits in educational area: promote skills, help review curricular and allows you to keep track student progress. Mathematics 3.0, are two software prototypes: one for the teacher and another one for the student, with this it, then seeks to promote skills in the resolution of numerical fractions at primary school in a playful way. This paper shows the results obtained in this project using the Prototype methodology.
\end{abstract}

Mobile apps, Numerical fractions, Video game cast technology

\begin{abstract}
Resumen
Cuando se habla de video juegos, los asociamos con el entretenimiento, pero su uso también tiene amplios beneficios educativos: fomenta las competencias, ayuda a repasar materias curriculares y permite llevar un registro de los progresos o avances del estudiante. Matemáticas 3.0, son dos prototipos de software: uno para el profesor y otro para el alumno, lo que se busca, es fomentar las competencias matemáticas a nivel de educación primaria, para la resolución de fracciones de manera lúdica. Este artículo muestra los resultados obtenidos en el proyecto y la metodología de desarrollo por Prototipos
\end{abstract}

Aplicación móvil, Representación de fracciones, Video juegos cas

Citation: QUIJANO-ABAN, Víctor Manuel, CERVERA-EVIA, Gimer Amilcar, MOO-PECH, José Guadalupe and QUIJANO-CRUZ, Bonesí. Mathematics 3.0 fraction squares, an educational video game for ludic use in classroom. Journal of Systems and Educational Management. 2020. 7-20: 26-32.

\footnotetext{
*Correspondence to Author (Email: edna_alvarez30@yahoo.com.mx)

$\dagger$ Researcher contributing as first Author.
} 


\section{Introduction}

In Mexico, only 5.1\% of third-year high school students can solve a mathematical problem by combining fractional and decimal numbers, according to the 2017 National Results of the Planea Test, which included the sample from the National Institute for Educational Evaluation (INEE, 2017). In 2019, the Secretary of Public Education, in coordination with the state educational authorities, carried out the application of the Plan Basic Education 3er test. Secondary grade to 1'056,701 students corresponding to 34,209 secondary, public and private schools across the country. With Planea, mathematics, language and communication were evaluated, and the results are expected to be comparable with those of 2017 and 2018 (PLANEA, 2019). Today in 2020, it will be difficult to compare the results, since INEE did not apply the corresponding sample, due to a budget cut last year.

One way to tackle the problem of low school achievement is to interest infant students in solving problems of daily life through play. A well-chosen game can be used to: introduce a topic, help to better understand the concepts, strengthen those already acquired, acquire skill in an algorithm or discover the importance of a property, also reinforce automatisms and consolidate content seen in class. The game helps students to acquire skills in the mathematical development of their knowledge. A class with a game is a motivated session from start to finish, it produces enthusiasm, fun, interest, unlocking, and a taste for studying and knowing more mathematics (Salvador, 2017).

The game constitutes a form of relationship and communication between the students and an instrument of assimilation and integration in the "world of adults". It has a clear educational value and turns out to be a methodological element. However, most educational systems consider it an unserious activity, not adequate for the learning processes that take place in the classroom. The game is a didactic instrument that can help us in an active pedagogy, to "do math in the math class", as opposed to passive, repetitive, verbal learning; to take into account the intellectual and affective processes for: the improvement of attitudes, exchanges of points of view, active participation, teamwork, promoting creativity and imagination (Salvador, 2017).
An educational mobile application is the assimilation instrument proposal for this work. Today, most students have portable devices at their fingertips. A mobile application are small, simple and elegant applications called "apps", which fulfill specific functions on an electronic tablet or on a smartphone (Johnson et al., 2012). In view of the latest technological advances, it is necessary to take into account that the learning process of the students has varied, their same information processing is not the same as some years ago (Duran-Quispe, 2020).

It would also be desirable to ask the educational authorities to get hold of educational materials and that they arrive every year at the Educational Institutions, in order to be used in teaching, learning and developing skills in students (Cruz-Calle, 2020).

\section{Fraction Talks}

Professor Nat Banting created a technique called "Fraction Talks". This consists of drawing fractional square figures using pencil and paper to improve the reasoning of their students. Squares divided by straight lines, when joined with others, form new flat geometric figures: squares, rectangles and triangles. The fractional square is called the "Fraction Square" (Banting, 2020).

The teacher in the classroom performs an activity that consists of introducing students to one or more "Fraction Squares". For example, color some of the sections in the "Fraction Square" and ask students what fraction of the illuminated part or portion represents the entire square. Students should reason and record on an answer sheet. As the days go by, the teacher keeps a history of the answers that his students have, so that he can evaluate his reasoning ability related to fractions. See Figure 1. 


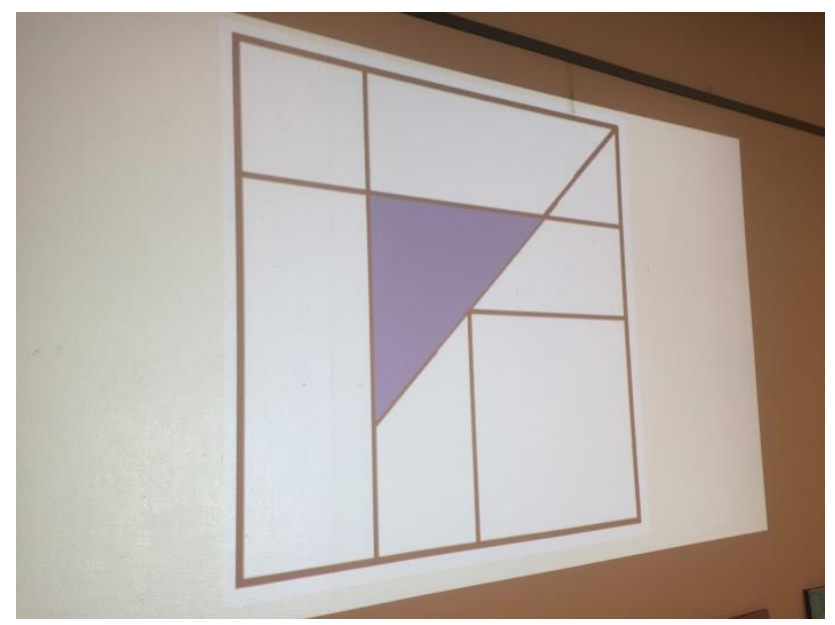

Figure 1 Fraction Talks

Source: (Banting, 2020)

Banting's work is interesting, since: it reinforces, interests and unlocks the student in the classroom and gradually assimilates the use of fundamental mathematical concepts for the following courses. Concepts such as: fraction, representation of fractions and fractional unit. Remember that the fractional unit is each of the parts obtained by dividing the unit into $\mathrm{n}$ equal parts (Crilly, 2016).

\section{Educational video games}

Video games are electronic programs that involve the interaction of one or more people with a machine or "interface" that generates graphics (Prensky, 2001).

Video games have been gaining more public presence in recent decades. These have transcended their initial role as a source of entertainment for children and have become a cultural product (Albarracín et al., 2017). The target audience has expanded its age range, due to the increase in the number and type of devices that it is possible to play on: laptops, smartphones and more recently consoles.

Video games exist thanks to electronics and computers, several examples: "Pong, Pacman, Space Invaders, etc". None of them would exist without the massive use of the personal computer and the television screen. The story begins in 1972, when a strange game booth appears installed in the Andy Capp's bar in the USA. This one looked a bit like pinball machines, but instead of a game table it had a television (Pérez-Latorre, 2010). The game called Pong and created by Nolan Bushnell and Ted Dabney, later founding young engineers of the Atari company (Kent, 2001).
Video games can be considered tools for learning. Currently, video games have characteristics that make them attractive to players and give them great potential as instruments to learn or develop specific strategies for acquiring knowledge (Gros, 2007).

Other characteristics of video games as tools in educational settings are: competition, the presence of objectives, the existence of welldefined rules and the need to make decisions at the moment (Charsky, 2010). See Figure 2.

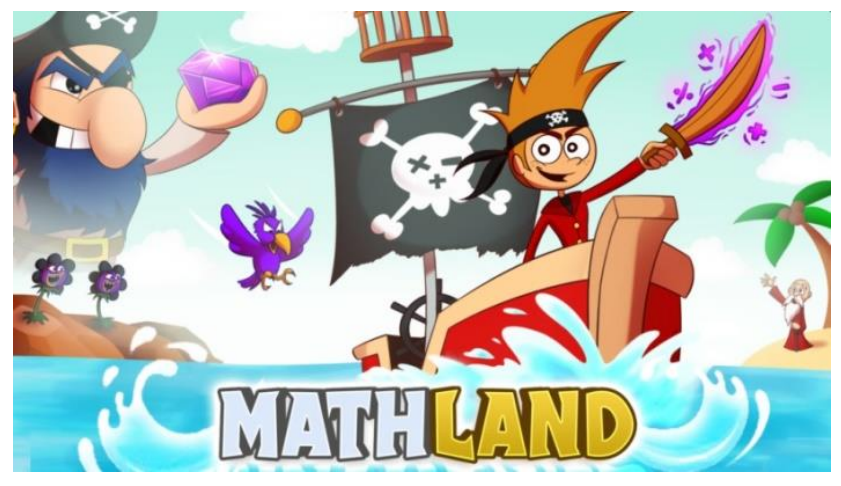

Figure 2 Educational video game Source: (DIDACTOONS, 2020)

\section{Chromecast $^{\mathrm{TM}}$ device}

The ChromeCast TM is a "dongle" or small device with an HDMI connection port (HighDefinition Multimedia Interface), it connects to a television and is used to play multimedia content and the internet (GOOGLE, 2020). Once the television is turned on, a configuration app is downloaded. The app configures ChromeCast TM and connects to the closest Wi-Fi network. Once the device is configured, users can download compatible applications, such as a video game developed in this project.

The Chromecast TM device is shaped like a circular disk and weighs 39 grams, as shown in Figure 3. Inside there is a powerful device to connect to the internet, it already has a dual core $1.3 \mathrm{GHz}$ processor and 512MB of RAM. It also complies with connection standards are $802.11 \mathrm{~b}$ / g / n / ac Wi-Fi (2.4 GHz / $5 \mathrm{GHz})$. A new model of the device is currently available. 


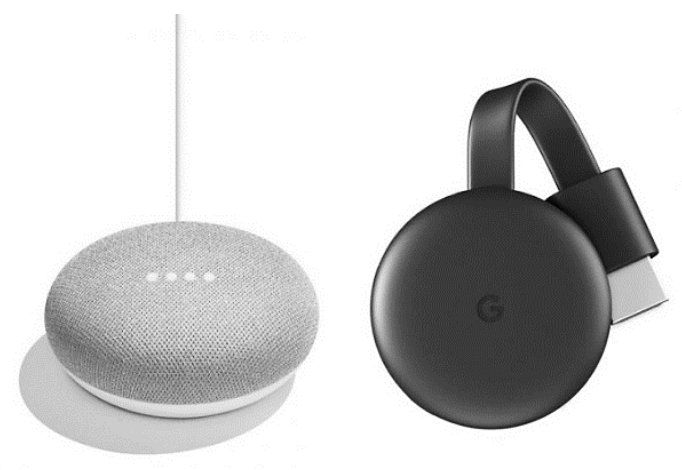

Figure 3 Chromecast TM device

Source: (GOOGLE, 2020)

\section{Methodology}

This section describes the prototyping methodology. It is the prototyping of software applications, which initially show little functionality. The process follows an iterative development cycle that gradually adds new features until the final product is finished. (Sommerville, 2011)

Below are the main activities to develop a prototype:

1) Identification of requirements.

2) Development of the initial prototype.

3) Review of the prototype.

4) Improve the prototype.

\section{Prototype one}

The first prototype was a web application to generate "Fraction Squares", that is, a puzzle made up of flat geometric figures that can be of different colors and sizes as already mentioned. See Figure 4.

With the following user requirements:

i. Draw squares, rectangles, and triangles to form puzzles.

ii. Select the fraction that represents the Figure.

iii. Draw right triangles, isosceles or scalenes according to the fraction they represent.

iv. Select the color of the figures.

v. Make the figures move up, down, left, and right. vi. Rotate rectangles and triangles.

vii. Rotate triangles.

viii. The fractions that the squares can occupy are $1 / 4,1 / 16,1 / 64$ and $1 / 256$.

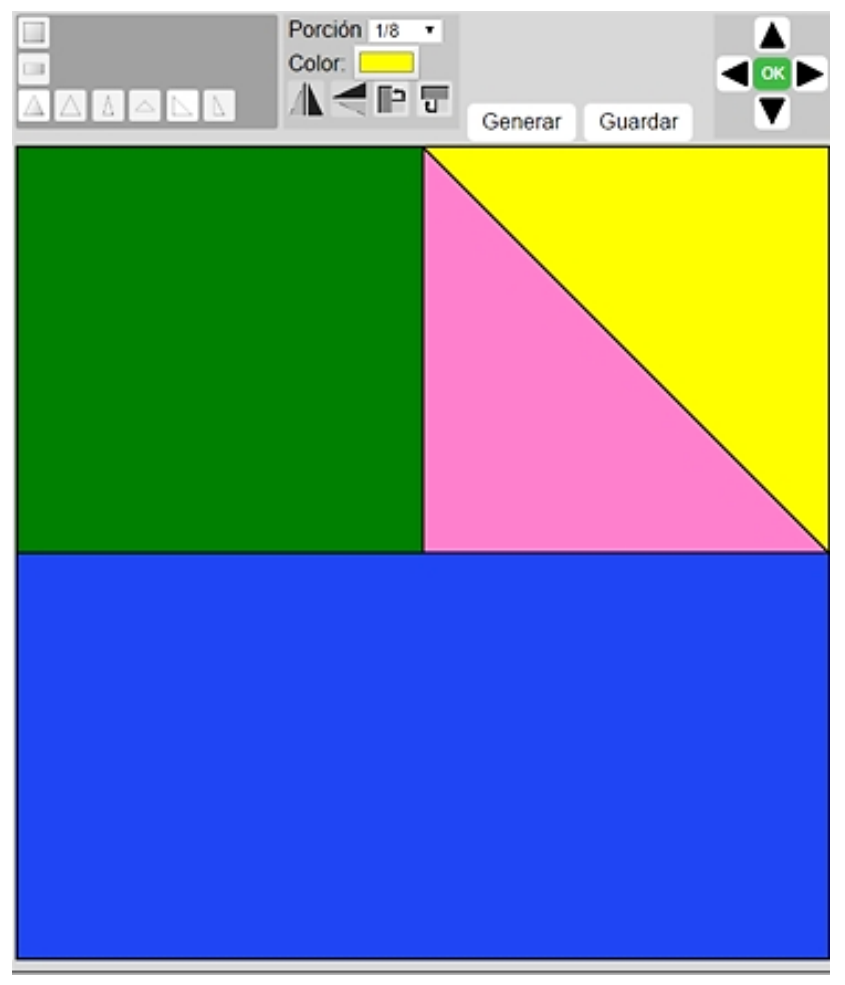

Figure 4 Prototype one

Source: self made

\section{Prototype two}

Prototype One was reviewed and modified to make it a Chromecast TM app. That is, adding software libraries to a Chrome app (GOOGLE, 2020). A Chromecast TM application is defined as the sum of two applications running at the same time: "the sender and the receiver". The "sender application" is installed on mobile devices and the "receiver application" is installed on the Chromecast TM. In the end, they interact with TV. See Figure 5.

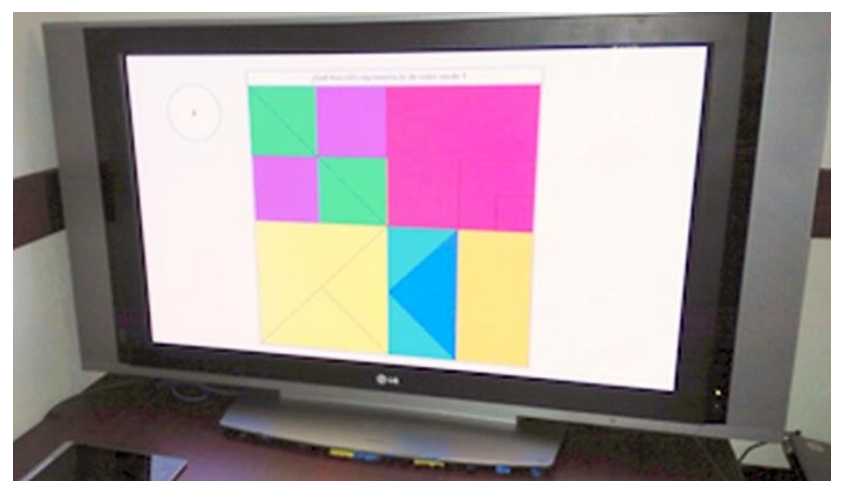

Figure 5 Prototype two Source: self made

QUIJANO-ABAN, Víctor Manuel, CERVERA-EVIA, Gimer Amilcar, MOO-PECH, José Guadalupe and QUIJANO-CRUZ, Bonesí. Mathematics 3.0 fraction squares, an educational video game for ludic use in classroom. Journal of Systems and Educational Management. 2020 


\section{Prototype three}

With the previous prototype, the following requirements are requested to be added:

i. Puzzles can be added to containers called challenges.

ii. The puzzles can be used in as many challenges as desired and can also be repeated in the same challenge.

iii. A list is requested to add new puzzles.

iv. A list of challenges is requested so that new challenges can be created and the desired puzzles can be assigned.

Lists and challenges are managed in this prototype. A challenge is an activity that can include one or more puzzles and the teacher decides when to apply by dates (activity calendar). In the "receiver application" the methods and user interface to manage the puzzle list by challenge are added, as can be seen in Figure 6.

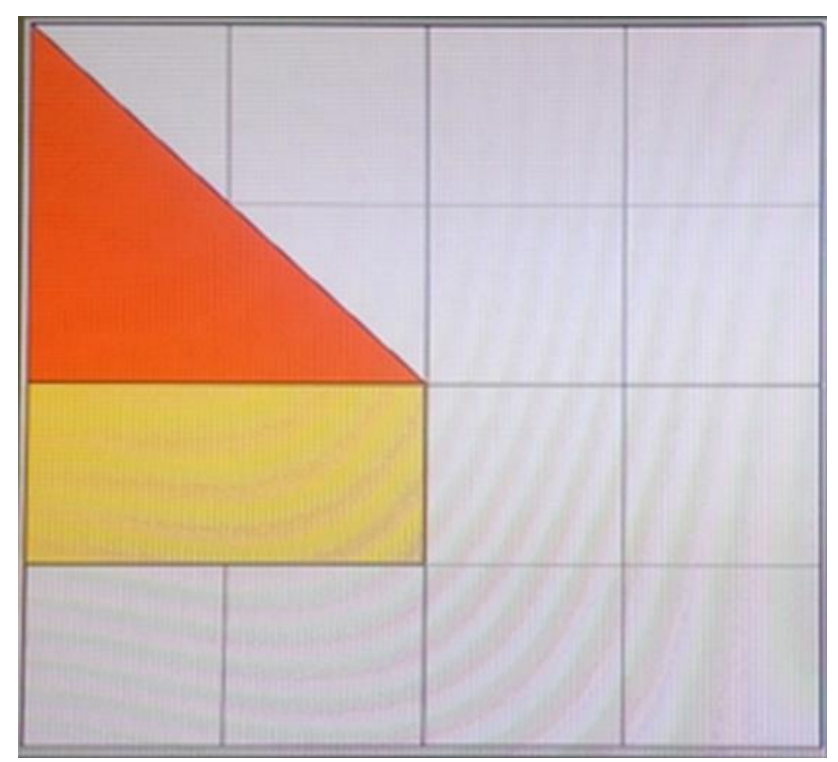

Figure 6 Prototype three

Source: self made

The "sender application" has been modified to allow you to create puzzles as in the previous prototype, but also have the option of creating new challenges and adding previously made puzzles to it from the puzzle list. See the graphical interface in Figure 7.

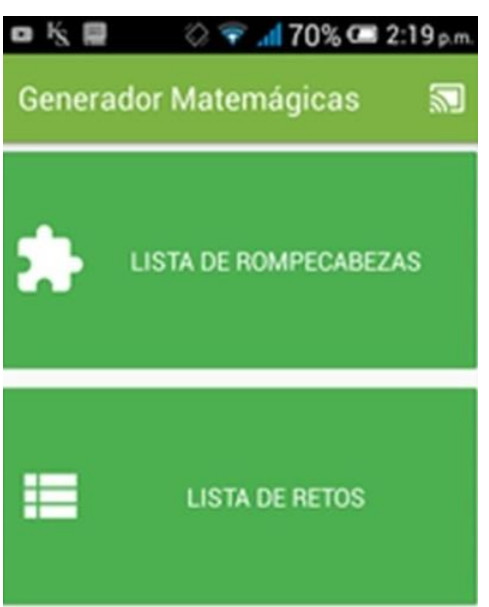

Figure 7 Graphical interface of the mobile app Source: self made

\section{Prototype four}

Here a database was added to store the questionanswer relationship in a table called Challenges_Puzzle. In addition the following requirements are added:

i. Each puzzle belonging to a challenge can be assigned a question and an answer.

ii. The challenges can be published to be used in the mobile application.

With the "sender application", a screen was added to enter questions and answers. There are three types of possible answers: those that indicate integers, fractions and colors. In this prototype only the response in the form of fractions was used. See Figure 8. 


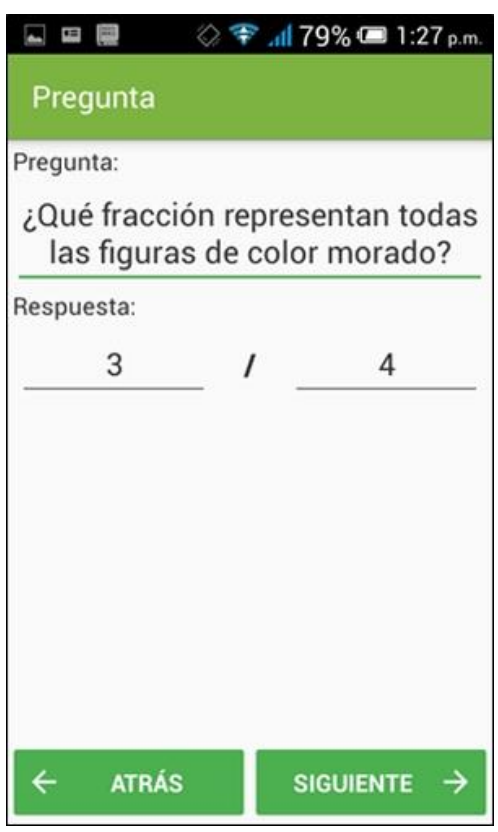

Figure 8 Prototype four

Source: self made

\section{Results}

Finally, an application for the student was created, following the previous development process, it is a prototype consisting of: a receiving web application and a transmitting application for mobile devices with Android operating system.

The application met the following requirements:

i. Use and synchronization of up to five Android mobile devices.

ii. Students will be able to enter their name to play.

iii. The correct answer must add points to the corresponding student.

iv. The game must show the points obtained per student.

Next, a test carried out with the prototype is presented. Start with a question and wait for the first answer, then move on to the next question. The evaluation of results is done at the end of the game. This test was carried out with students from a primary school near the University. The test results are presented below. See Table 1.

\begin{tabular}{|l|r|r|r|}
\hline Question & Player 1 & Player 2 & Player 3 \\
\hline Question 1 & 0 & 0 & 1 \\
\hline Question 2 & 1 & 0 & 0 \\
\hline Question 3 & 0 & 1 & 0 \\
\hline Question 4 & 0 & 0 & 1 \\
\hline Question 5 & 0 & 0 & 0 \\
\hline Question 6 & 0 & 0 & 1 \\
\hline
\end{tabular}

Table 1 Test results

Source: self made

The winner was Player 3, with three points in total, after answering Questions 1, 4 and 6. It can also be seen that Question 5 was not answered correctly by any participant.

With respect to the electronic equipment used, they functioned smoothly to work on most devices available on the market. In addition, the challenges in the equipment used were shown without distortion: a 50 "TV, a laptop with a 15 " screen, a smartphone and three electronic tablets with different screen dimensions. See Figure 9.

The project schedule estimated one month per prototype and the total project time of four months. The cost per prototype was approximately \$500 USD, this includes: the development time of a fellow, the time of two consultants, purchase of equipment, payment of software licenses, consumption of electrical energy and consumption of internet access.

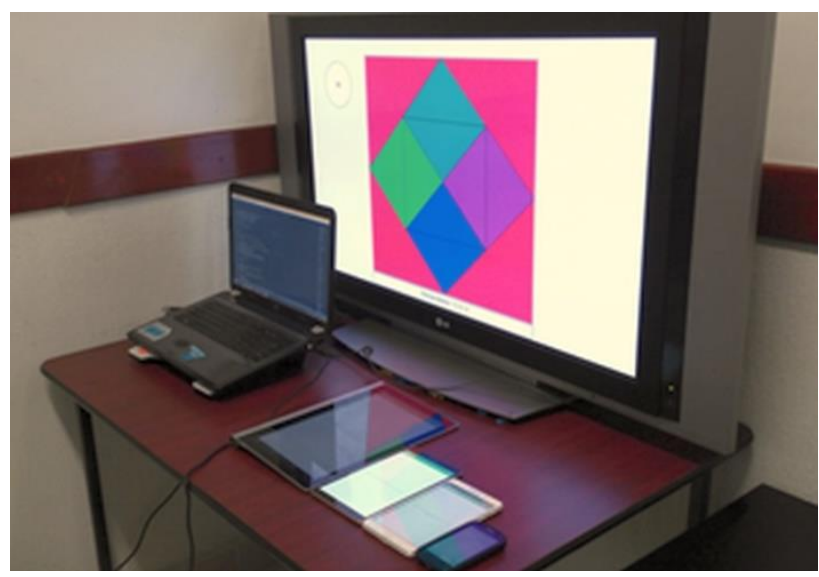

Figure 9 Devices used in the project Source: self made

\section{Conclusions}

Mathematics 3.0, is an educational mobile application that helps solve mathematical problems of elementary school students on the topic of fractions and representation of fractions. The starting point was the technique developed in Professor Banting's "Fraction Talks". 
The end result is a learning tool, since the teacher imagines and designs "Fracction Squares" figures and his students must solve these mathematical challenges with the video game. The video game can be run on more than one device at the same time: a TV, a smartphone, and a Google ChromeCast TM device.

With this tool it was possible to: generate weekly tasks, encourage participatory student work and help consolidate the content seen in class. In addition, it has a progress record to identify which student needs advice or reinforcement on the topic of fractions.

It is suggested to continue with the prototype until having a final product available on the "play store" website for downloads.

\section{References}

Albarracin, L., Hernández-Sabate, A. \& Gorgorió, N. (2017). Los videojuegos como objeto de investigación en Educación Matemática. Modelling in Science Education and Learning. Volumen 10(1). pp.53-69.

Banting, N. (2020). Sitio Fraction Talks. Recuperado el 15 de febrero de 2020, desde http://fractiontalks.com/about-2/

Charsky, D. (2010). From edutainment to serious games: A change in the use of game characteristics. Games and culture, Vol. 5, N. 2, pp.177-198.

Crilly, T. (2016). 50 Cosas que hay que saber sobre matemáticas. $3^{\mathrm{a}}$. Ed. Editorial Planeta. México.

Cruz Calle, Y. (2020). Talleres de robótica educativa con materiales lego, para mejorar el aprendizaje en el área de matemática, en los estudiantes del primer grado de secundaria de la institución educativa particular "Excelencia", Chiclayo 2018.

DIDACTOONS. (2020). Estudio de video juegos educativos. Recuperado el 20 de marzo de 2020, desde https://www.didactoons.com/

Duran Quispe, D. O. (2020). Influencia de un Módulo Didáctico en el Aprendizaje de la
Matemática, en Estudiantes del Nivel Secundario de una Institución Educativa del Distrito San Juan de Lurigancho, 2019.

GOOGLE. (2020). Sitio Google Cast. Recuperado el 25 de febrero de 2020, desde https://support.google.com/chromecastbuiltin/a nswer/6102923?hl=es-419\&ref_topic $=6102922$

Gros, B. (2007). Digital games in education: The design of games-based learning environments. Journal of Research on Technology in Education. Vol. 40, No. 1, pp.23-38.

INEE. (2017). Sitio web Instituto Nacional para la Evaluación de la Educación. Recuperado el 6 de enero de 2019, desde https://www.inee.edu.mx/evaluaciones/planea/r esultados-planea/

Johnson, L., Adams, S., \& Cummins, M. (2012). Informe Horizon del NMC: Edición para la enseñanza universitaria 2012. The New Media Consortium. EE.UU.

Kent, S. L. (2001). The ultimate history of videogames. Three Rivers Press. Nueva York.

Pérez-Latorre, O. (2010). Análisis de la significación del videojuego. Fundamentos teóricos del juego, el mundo narrativo y la enunciación interactiva como perspectivas de estudio del discurso. Tesis doctoral. Universidad Ponpeu-Fabra. Barcelona. España.

PLANEA. (2019). Sitio web Plan Nacional para la Evaluación de los Aprendizajes. Recuperado el 10 de enero de 2019., desde http://planea.sep.gob.mx/

Prensky, M. (2001). Digital game-based learning. Games for entertainment and learning. ACM Computers in Entertainment. Volumen 1(1), pp.1-4.

Salvador, A. (2017). El juego como recurso didáctico del aula de matemáticas. Universidad Politecnica de Madrid. España.

Sommerville, I. (2011). Ingeniería de software. 9a. Ed, Pearson. México. 